\title{
Reseña. María Pérez-Ugena, El uso on-line de la mediación, servicio de solución de conflictos: un instrumento para las situaciones de crisis. Madrid, España: Dykinson, 2020. ISBN 9788413247236
}

Puede afirmarse que la mediación es un instrumento idóneo en materia de resolución de conflictos. Tal aseveración resulta aplicable en el momento actual, pero, por sus prerrogativas inherentes, también a futuro. En efecto, en la práctica, la vía judicial ha demostrado no ser el mecanismo más efectivo. Como dice el refrán popular, más vale un mal acuerdo que un buen juicio, de resultado incierto y notablemente más costoso que el primero. De hecho, la pandemia que vivimos, a propósito de la COVID-19, ha paralizado, durante varios meses, la justicia de diversos Estados, entre los que se encuentra la española. Todo ello hay que sumarlo a una justicia desbordada — necesitada de personal- que ya acumulaba retrasos más que notables. En el caso concreto de España, han permanecido cerrados todos aquellos juzgados y tribunales que no eran reputados esenciales.

Después del fin del estado de alarma se ha puesto de relieve el importante colapso en la tramitación de los asuntos que ya estaban registrados en los juzgados — con carácter previo a la pandemia - y los que, a raíz del coronavirus, se están presentando en los juzgados y lo harán en los próximos meses — en los diversos órdenes jurisdiccionales-. Por todo ello, como se decía al comienzo de esta reseña, los mecanismos extrajudiciales de resolución de conflictos (MERC, en adelante), entre los que se encuentra la mediación, son un instrumento eficaz, rápido y económico para dar solución a los litigios civiles y mercantiles.

La obra que es objeto de reseña tiene como autora a María Pérez-Ugena, doctora en Derecho y profesora titular de la Universidad Rey Juan Carlos. La monografía consta de siete grandes apartados —además de la introducción y la bibliografía-, escritos de manera magistral, pues, además de presentar un contenido riguroso, resultan de fácil lectura. Como el lector tomará conciencia, representa una reflexión, profunda y brillante, sobre uno de los instrumentos paradigmáticos en materia de ADR (Alternative Dispute Resolution). Constituye una aproximación novedosa de gran utilidad para quien se acerque a este fenómeno de marcada aplicación práctica. 
El primero de los capítulos alude al conflicto como objeto de la mediación. Como señala la autora, los orígenes de la mediación son relativamente recientes, dado que podemos situarlos en la década de los sesenta en los Estados Unidos. Lo que caracteriza a la mediación es que la solución del conflicto no se hace recaer en el mediador, sino en las propias partes. El mediador ha de ocupar una posición marcadamente neutral. Cabe destacar, asimismo, que la mediación constituye un procedimiento de naturaleza legal — ya que es objeto de regulación normativa - pero, además, tiene ciertos vínculos con la psicología. Como manifiesta la autora, el conflicto es parte de la vida ordinaria. Por lo que respecta a los elementos del conflicto, la autora analiza, de manera independiente, los actores, las causas que lo originan y el elemento temporal por el que atraviesa el conflicto.

El sistema de mediación se fundamenta en ciertos principios informadores que son objeto de análisis en el capítulo siguiente. Sin su concurrencia, una mediación y el acuerdo que se derive de esta serían nulos. Asimismo, vulneraría las garantías consustanciales a la tutela judicial efectiva. Dentro de dichos principios, cabe referirse a los siguientes: voluntariedad; libre disposición de la materia; igualdad de oportunidades; imparcialidad; neutralidad y confidencialidad. En materia de imparcialidad, cabe referirse al Código de Conducta Europeo de 2004 sobre la materia. Además de los mencionados principios, imperan determinadas reglas o directrices que deben observar las partes en su actuación. Se trata, entre otros, de la buena fe, el respeto mutuo y su deber de colaboración y apoyo al mediador.

Los caracteres del procedimiento de mediación se analizan en el capítulo tercero. La mediación es complementaria a la jurisdicción de la que no es ni antagónica ni excluyente. Asimismo, se administra por personas no incluidas en el Poder Judicial. Finalmente, es alternativa a la vía judicial, pues no se puede resolver el conflicto por las dos vías de manera simultánea. También cabe reseñar que se trata de un procedimiento de carácter flexible que, como la autora indica, pertenece a las partes. Es necesario que el mediador cite a las partes a una primera sesión informativa. Posteriormente, constituida la mediación, se debe firmar el acta de iniciación, comenzando el desarrollo del procedimiento propiamente dicho. De la sesión constitutiva se levantará un acta. La última fase del procedimiento — terminación — podrá cerrarse con acuerdo — siendo posibles los acuerdos de carácter parcial— o sin acuerdo. Especialmente sugerentes resultan las apreciaciones formuladas a propósito de la ejecución del acuerdo de mediación. En el supuesto de que se quiera convertir a título ejecutivo habrá de elevarse 
a escritura pública. En puridad, los acuerdos de mediación son títulos ejecutivos de índole extrajudicial. La ejecución forzosa de los convenios de mediación es competencia de los tribunales de justicia.

Para entender con más profundidad el proceso de mediación — repárese en que es de carácter autocompositivo- hay que conocer la posición de las partes en el proceso, así como el papel que desempeña el mediador. Tales aspectos son objeto de análisis, de forma independiente, en el capítulo cuarto. Las partes, y no el mediador, son las verdaderas protagonistas y deben actuar conforme a los principios de lealtad, buena fe y respeto mutuo. En cuanto al rol del mediador, es fundamental. Ahora bien, debemos partir de la base de que la labor del mediador no es una terapia ni pretende ser un asesoramiento jurídico, si bien el mediador es un psicólogo o abogado. El mediador debe situarse en un plano de igualdad con las partes. Debe posicionarse frente a las partes en una posición que facilite la consecución de un acuerdo. El mediador, como establece la autora, debe efectuar un ejercicio de respeto a las partes. El Código de Conducta Europeo para Mediadores señala que el mediador no debería únicamente actuar imparcialmente respecto a las partes, sino, con carácter complementario, esforzarse en demostrar tal imparcialidad.

Las técnicas aplicables al procedimiento de mediación se contemplan en el capítulo quinto. Tales métodos proceden de la psicología y de la mediación. La autora expone las diversas etapas del proceso y las técnicas de mediación que habitualmente se aplican a cada una de las fases del proceso. En cualquier caso, debe tomarse conciencia de que estamos ante un procedimiento flexible y, en función a la casuística, será necesaria la adaptación de las técnicas con las que dispone el mediador de la forma que más convenga.

El capítulo sexto se refiere a las particularidades que se plantean en el ámbito digital. Se trata de un ámbito con una extraordinaria proyección de futuro. En este caso, la mediación aprovecha las nuevas tecnologías con el objeto de gestionar el proceso y comunicar a las partes con el mediador. Nótese que, como bien dispone la autora, no estamos ante un sistema distinto, sino ante el mismo que debe gestionarse con todas las garantías y con suficiente calidad. Muy oportuna resulta la distinción operada entre la mediación online y las ODR (Online Dispute Resolution). La mediación online sería una especie o tipología de ODR. A propósito del tema que se está abordando, cabe destacar que la mediación ya recurre a la inteligencia artificial, pudiendo incluso efectuar 
divorcios. Mediadores australianos han diseñado una herramienta para descongestionar los juzgados. Nótese que el sistema no divorcia per se, sino que permite que se llegue a un acuerdo de las partes en la materia. El sistema formula una invitación al acuerdo después de estudiar el algoritmo de diversos puntos, como, entre otros, la cantidad de activos a compartir, otros acuerdos alcanzados con carácter pretérito por otras parejas en situaciones parecidas, o aplicando los criterios tenidos en cuenta por los tribunales en esta modalidad de litigios.

El último capítulo alude a las ventajas que ostenta la mediación respecto a la vía judicial. Dentro de estas, podemos mencionar las siguientes: rapidez y agilidad; confidencialidad; flexibilidad; interés mutuo; mayor eficacia en la resolución del litigio; mejora de las relaciones; reducción de costes; especialización; facilidades en conflictos transfronterizos y la posibilidad de la resolución digital de conflictos.

En definitiva, la obra recensionada se erige en una aportación muy significativa respecto a un tema de importante actualidad, la mediación, cuya relevancia en el tráfico jurídico es cada vez más notable. La monografía realizada por la profesora Pérez-Ugena es una investigación pionera, en el ámbito de los MERC que, por sus caracteres inherentes, constituye una obra imprescindible tanto para el académico en sentido amplio como para los prácticos del Derecho y otras disciplinas. Dentro de las prerrogativas, podríamos citar, sin ánimo agotador, las siguientes: su hilo conductor lógico y secuencial; su técnica jurídica rigurosa y su redacción cuidada.

Dr. David López Jiménez ORCID: 0000-0002-7013-9556

EAE Business School, España Correo: dlopez@eae.es 